\title{
Alaryngeal Speech
}

National Cancer Institute

\section{Source}

National Cancer Institute. Alaryngeal Speech. NCI Thesaurus. Code C17159.

Instructional activity designed to teach patients how to vocalize with a non-functioning or absent larynx. 